\title{
James's Epistemology and the Will to Believe
}

\section{Christopher Hookway}

\section{(2) OpenEdition}

\section{Journals}

Electronic version

URL: http://journals.openedition.org/ejpap/865

DOI: $10.4000 /$ ejpap.865

ISSN: 2036-4091

Publisher

Associazione Pragma

\section{Electronic reference}

Christopher Hookway, « James's Epistemology and the Will to Believe », European Journal of Pragmatism and American Philosophy [Online], III-1 | 2011, Online since 01 July 2011, connection on 19 April 2019. URL : http://journals.openedition.org/ejpap/865 ; DOI : 10.4000/ejpap.865

This text was automatically generated on 19 April 2019

\section{(c) $(1)$}

Author retains copyright and grants the European Journal of Pragmatism and American Philosophy right of first publication with the work simultaneously licensed under a Creative Commons AttributionNonCommercial-NoDerivatives 4.0 International License. 


\title{
James's Epistemology and the Will to Believe
}

\author{
Christopher Hookway
}

1 When we look for distinctively pragmatist contributions to epistemology, we are likely to turn to Peirce's criticisms of Cartesianism and his insights into induction, adbuction and the method of science. We may also examine Dewey's criticisms of the "Quest for Certainty" and his work in what he called "logic" and the theory of inquiry. We are less likely to turn to the writings of William James whose interests and insights may be supposed to lie elsewhere. The aim of this paper is to identify some Jamesian contributions to our under- standing of epistemic norms. I shall argue that a number of views which have become prominent in contemporary epistemology, and some of which are often described as pragmatist approaches to epistemology can be traced to the writings of James. And I shall consider how far the doctrine of the "Will to Believe" is an application of these epistemological views. I shall argue that James was an earlier defender of epistemic contextualism and epistemic conservatism, and I shall also suggest that some of his insights are in harmony with contemporary virtue epistemology.

\section{Epistemic Contextualism}

2 First we shall examine some evidence that James was sympathetic to epistemic contextualism. Contextualists hold that whether a belief counts as knowledge, or whether it is justified, can depend upon the context of the believer or the context of the person who is evaluating the belief (see DeRose 1992). In some circumstances, higher standards are required for a belief to count as justified than in others. For example, suppose that I am in the supermarket and the question arises whether we need to buy lasagne. Trusting my memory that I saw lasagne in the pantry yesterday morning, I dismiss the question, confident that I know that we possess lasagne. But suppose that I have already planned an important dinner for tomorrow, and the availability of lasagne is an indispensable ingredient of it. Since my memory may be fallible and the consequences of my being 
wrong could be serious, I wouldn't claim knowledge that we possess lasagne. This has often been thought to offer a strategy for defusing skepticism. The context in which we can take seriously the possibility that we are dreaming or deceived by an evil demon may not be relevant to everyday beliefs that we are using to guide our actions. Contextualists often invoke the phenomenon of "pragmatic encroachment": the standards of justification that we employ in a particular context depend upon how the belief in question is to be used and upon how damaging it would be if the belief turned out to be false. Thus more (or better) evidence is required for belief in results of medical research than for casual reflection.

What is the evidence that William James would have favoured epistemic contextualism? The place to begin is "The will to believe," James's response to Clifford's account of the "Ethics of belief." James is responding to one of the fundamental principles of W.K.Clifford's "Ethics of belief." According to Clifford:

It is wrong always, everywhere, and for everyone, to believe anything upon insufficient evidence. (Clifford 1897: 186)

4 For Clifford, this rule is an ethical principle: "Belief is desecrated when given to unproved and unquestioned statements for the solace and private pleasure of the believer." Such belief is "sinful" (ibid.). As is well known, Clifford used this principle to mandate agnosticism about religious matters.

James's paper argues that, in appropriate circumstances, it can be rational or appropriate to form or retain beliefs when you possess relatively little, or even no, relevant evidence. His argument rests upon identifying the particular circumstances in which belief can be formed on "passional grounds." In identifying these circumstances, he is specifying the sort of context in which belief may be legitimate when we have no or little relevant evidence.

6 James specifies the contextual requirements for such belief to be legitimate. One requirement is that the correctness of the belief in question cannot be settled intellectually. Others concern the practical urgency of settling whether to endorse the proposition in question, and the lack of alternative courses of action which do not depend upon this belief. This urgency can depend upon the risks involved in suspending judgment in the proposition in question or in arriving at a belief which is in fact fals (James 1897: 2-4).

7 A contextualist response to Clifford's position can take two different forms. One is to observe that the term "sufficient evidence" is vague or context relative. We may suppose that in different contexts, different amounts of evidence will count as sufficient. Someone may argue that the amount of evidence that would be sufficient for a casual belief where the risk of error has little weight would be insufficient when engaging in, for example, medical research. In that case, we could continue to endorse the principle as it was formulated by Clifford, but deny that it has the consequences which Clifford expects it to have. Alternatively, James could hold that Clifford's principle is applicable in some circumstances but not in others. As we shall see, James's response is of the second of these kinds. He does not address how we should understand when evidence is sufficient.

In section VII of "The Will to Belief," James writes:

There are two ways of looking at our duty in the matter of opinion, - ways entirely different, and yet ways about whose different the theory of knowledge seems hitherto have shown very little concern. We must know the truth; and we must avoid error. (1897: 17) 
These "two separable laws" "Believe truth!" and "Shun error" can be in tension, and "by choosing between them we may end by coloring differently our whole intellectual life" (1897: 18). James's view is that in some contexts, we should give prominence to one of these laws, and in other contexts, we should rely upon the other. We want to obtain truth and we want to avoid falsehood, and we weigh these desiderata differently in different contexts. In effect, we have to choose between competing (prima facie) duties, and context determines which of those duties we should give priority to in a particular case. Clifford's view appears to be that one of these duties (the avoidance of error) should be given absolute priority.

In science, he tells us, "and even in human affairs in general, the need of acting is seldom so urgent that a false belief to act on is better than no belief at all." In science, we value the avoidance of error more than obtaining truth: we can wait to reach the truth. But "Moral questions present themselves as questions whose solution cannot wait for sensible proof" (James 1897: 22). And the "Law courts have to decide on the basis of the best evidence attainable for the moment, for the judge's duty is to make laws as well as to ascertain it" (James 1897: 20). James presents the issue by saying that there are two laws, and we can only follow one of them on any specific occasion, so we need an account of which we should follow. A more plausible kind of pragmatism would hold that we have, not two laws but rather two values which carry different weights in different circumstances, making use of Bayesian ideas and decision theory (Hookway 2005, Levi 1998). Although James's way of describing the issue may have to be rejected, it is evidently a precursor of these more sophisticated views.

\section{Contextualism and the Will to Believe}

11 According to James, it is legitimate to believe propositions which cannot be settled by intellectual means when the choice meets some specific contextual circumstances. We can illustrate this by reference to one of James's examples. Suppose that I am about to be interviewed for a job, and my current evidence does not give me conclusive reasons for thinking that I will. I am currently undecided about whether my application for the job will be successful. It is important to me that I get the job, and I believe that it is possible, to some degree at least, that I will. Let us suppose that I also believe, quite reasonably, that if I am confident that I will succeed, I am likely to perform much more impressively in the interview than I would if I was uncertain about the outcome. If I can bring myself to believe that I will succeed, then I am not irrational to do so. I should not follow Clifford's apparent advice that I am irresponsible if I do not carefully evaluate my evidence and, recognizing that it does not settle the matter, abandon my belief and take an agonistic stance on the matter. As is well known, James discerns a similar structure in our reflections about whether we should retain, or perhaps adopt, religious belief. If I recognize that I face a "genuine option" which is "forced" and "momentous," and it cannot be resolved by intellectual means, I am not irrational to hold on to a belief for which I do not possess conclusive evidence (James 1897: 2-4).

Interestingly, the philosopher of science, Bas van Fraassen describes James's strategy in "Belief and the will" (1985) as the application to the case of religious belief of a strategy of belief formation which is widespread in science. He interprets Clifford's notion of "sufficient evidence" as conclusive evidence, and argues that when we accept beliefs on 
inductive grounds, we have to rely upon non-evidential considerations. Perhaps it is rational to trust our current opinions even if, in a fallibilist spirit, we think there is a good chance that they will be refuted by further evidence. This is because doing so will be the best means of advancing our long term scientific goals of improving our scientific understanding of our surroundings. If we believe propositions on less than conclusive evidence, we initiate processes that will lead to a more thorough testing of the hypothesis, and perhaps to a better articulation of it. So van Fraassen's view is that, both in the case of religious belief and scientific belief, it is a good strategy to believe propositions for which we have less than "sufficient" evidence, because we have nonevidential considerations for doing so.

\section{James and Peirce on Science and Belief: A Comparison}

13 In 1998, Peirce gave a series of lectures to the "Cambridge Conferences." They were subsequently published in Reasoning and the Logic of Things (Peirce 1992). Some scholars interpret the first of these lectures, "Philosophy and the conduct of life" as a rejection of James's doc trine of the Will to Belief. Their differences may be less than is often supposed. We can see this by considering their views about the role of belief in science.

14 James holds that "whenever the option of losing truth and gaining it is not momentous, we can throw the chance of gaining truth away and at any rate save ourselves from any risk of believing falsehood." We can do this by suspending judgment, by neither believing nor disbelieving the proposition in question. According to James, this is almost always the case in science.

The most useful investigator, because the most sensitive observer, is always he whose eager interest in one side of the question is balanced by an equally keen nervousness lest he become deceived.

Science has organized this nervousness into a regular technique, her so-called method of verification; and she has fallen so deeply in love with the method that one may say that she has ceased to care for truth by itself at all. (James 1897: 21)

So James is ready to follow Clifford's rule in serious scientific research. Indeed, if truth is presented "in affirmative form," "she would decline to touch it" (ibid.). Agreeing with Clifford, James endorses the observation that "such truth as that [...] would be stolen in defiance of [science's] duty to mankind" (ibid.).

In Peirce's Cambridge lectures (Peirce 1992: 111-2) he agreed with James. He insists that what is properly and usually called belief [...] has no place in science at all [...] because "nothing is vital for science; nothing can be" (CP1.635). "The true scientific investigator completely loses sight of the utility of what he is about" (CP1.619). Peirce seems to hold that, in pure science, the avoidance of error should be given priority. This provides an interesting contrast between Peirce and van Fraassen. Peirce holds that current philosophical results are not a matter of belief but are, rather, the objects of more tentative forms of acceptance. But Van Fraassen seems to think that current scientific results are believed, but that the belief in is not supported by "sufficient" evidence, and the belief has a non-evidential basis. The differences noted here may be less significant than they appear: Peirce, as well as denying that we believe current scientific results, talks about "scientific belief," a state which is more provisional or tentative than full belief. Even if fallibilist scientists allow that the sort of acceptance scientific belief involves is 
more tentative than ordinary common-sense beliefs, if may be appropriate to treat this as a variety of (scientific) belief. However it is also important to recognize that the religious belief which James obtains on the basis of his "passional considerations" could not be a kind of tentative acceptance of the sort that Peirce and Popper would say was appropriate for scientific opinions.

Peirce's agreement with James goes further. When we are concerned with "vitally important issues," matters of urgency and importance for our lives, we should not trust to fallible scientific results. In vital matters, "the principle on which we are willing to act is a belief" (1992: 112). "Theoretical knowledge, of science," he says, "has nothing directly to say concerning practical matters" (1992: 112). Whether we should believe depends upon context: we should be tentative about believing current scientific results; and whether we should believe is a function of how ready will be to risk possessing a false belief on the matter. Van Fraassen may suggest that James's doctrine of the will to believe should lead us to take such risks when acquiring scientific beliefs, while Peirce would not. But James's views here seem to be closer to Peirce's than to van Fraassen's. Both pragmatists have contextualist views about when we should be ready to believe a proposition.

\section{Epistemic Conservatism}

We now turn to the second epistemological position that is reflected in James's writings, epistemic conservatism. We can provide a positive justification for some of our beliefs. We can point to evidence that supports them or a proof that demonstrates their truth. However, for many of our beliefs, we can provide no positive justification at all. We may forget how we acquired them. They are things that we have learned but haven't forgotten. If we have no positive justification for accepting some proposition, are we justified in believing it? The argument of Descartes's first Meditation holds that if we lack positive justification for a belief, then this itself constitutes a reason for doubting it. Epistemic conservatives reject this Cartesian assumption. Beliefs are justified unless we have positive reason for doubting them:

If someone already believes some proposition, then they are prima facie rational in continuing to believe it.

You only need to be able to provide reasons for continuing to hold a settled belief if you are presented with a "defeater" for it, something that suggests that the proposition is false or something that suggests you were not entitled to hold it.

Beliefs are justified unless there is a positive reason for doubting them: the concept of a reason for doubt is more fundamental than the concept of a reason for belief. This opens up a range of interesting issues about just what constitutes a reason for doubting a stably held belief. Why are we justified in ignoring the sorts of hypothetical reasons for doubt which are proposed by proponents of skepticism?

This form of conservatism is often defended by philosophers sympathetic to the commonsense tradition. It is also found in Wittgenstein's On Certainty and it is sometimes assumed by epistemologists defending externalist views of justification and knowledge. It is also found in the writings of pragmatist philosophers such as Isaac Levi (1998) and Peirce (see Hookway 2008). Peirce calls upon philosophers "not to pretend to doubt in philosophy what we do not doubt in our hearts" (1868, EP1: 29). Later, in 1906, he wrote that "what 
one does not doubt cannot be rendered more satisfactory than it already is" (CP6.498). And Levi defended "the principle of doxastic inertia" which holds that "there is no need to justify current beliefs, only changes in belief" (Levi 1998: 78).

James's commitment to the principle of doxastic inertia is evident from his 1908 lectures on Pragmatism, especially in lecture II in which he explains "What pragmatism means" and introduces his pragmatist account of truth. Acknowledging the influence of Schiller and Dewey, he considers how we arrive at new opinions, concluding that process by which this occurs is always the same.

The individual has a stock of old opinions already, but he meets a new experience that puts them to a strain. Somebody contradicts them; or in a reflective moment he discovers that they contradict each other; or he hears of facts with which they are incompatible; or desires arise in him which they cease to satisfy. The result is an inward trouble to which his mind till then had been a stranger, and from which he seeks to escape by modifying his previous mass of opinions. He saves as much of it as he can, for in this matter of belief we are all extreme conservatives. So he tries to change first this opinion and then that [...] until at last some new idea comes up which he can graft upon the ancient stock with a minimum disturbance of the latter. (James 1907: 34)

James's conservatism is manifest when he writes that we "preserve the older stock of truths with a minimum of modification, stretching them enough to make them admit the novelty, but conceiving that in ways as familiar as the case leaves possible" (James 1907: 35).

The insistence on this conservatism, this preservation of the "older stock of belief," is very important for James. He suggests that taking this seriously was indispensable if we are to recognize what is wrong with many of the criticisms made of pragmatism. Indeed, he says that loyalty to the older truths "is the first principle in revising and forming our beliefs rationally" (ibid.: 35). Pragmatism's critics are disturbed by the suggestion that there is no independent or object constraint upon what we believe: perhaps, they suggest, we can reasonably accept anything which it suits our needs to believe. Rationalists and some other realists and empiricists offer different candidate explanations of why and how our opinions are constrained by reason, or by the facts, or by experience. Loyalty to the older facts provides another kind of constraint. They reflect what we know (fallibly) about reality and our determination to be loyal to these older facts and thus indicate thus we want to revise our beliefs in a way that preserves what we take ourselves to know. We trust our beliefs until given reason to doubt them, not whenever we think it would suit us to change them.

How does James's epistemic conservatism relate to the argument of "The will to believe"? It is useful to distinguish two versions of the sort of view that James defends, two contexts from which his argument may be employed.

First, consider the position of someone who currently holds religious belief. They don't reflect much upon the belief's evidential credentials, but they find holding such a belief ful- filling. Clifford would probably regard this person as epistemically irresponsible: we have an obligation to ensure that such a belief is, indeed, supported by "sufficient evidence." James's epistemic conservatism would give reason for rejecting this requirement. In most cases, beliefs are innocent unless we think there is a positive reason for doubting them. Perhaps the argument of "The will to believe" would provide additional support for resisting the demand that we investigate the epistemic credentials 
of the belief. It may be suggested that the suspicion that the belief has been sustained by non-evidential considerations does not provide positive reason for doubting it.

Second, consider the position of someone who is initially an agnostic about the existence of God. Clifford's view is such a person should proceed by collecting evidence, and their agnosticism should not be replaced by stable belief until they have "sufficient evidence" either for or against the truth of the religious proposition. This is the version that can seem problematic: James spears to recommend that this person should manipulate his beliefs by seeking out experiences which would contribute to the onset of religious belief. James's observation that a better title for his paper would have been "The right to believe" may support the first of these two positions, and it is significant that Peirce's view of the rationality of religious belief fist this view as well. Suspicious of any attempt to ground religious belief in arguments or theories, he held that "pretty nearly everybody more or less believes that God is real, including many of the scientific men who are accustomed to think the belief is entirely unfounded" (CP 6.496). Indeed, religious belief is manifested in attitudes and practices, and it would be "folly" to think that "metaphysical theory in regard to the mode of being of the perfect" could damage religious belief (W3: 322, and see Hookway 2000: chapter 11).

\section{Virtue Epistemology and Our Epistemic Temperaments}

So far, we have said little about the epistemic relevance of "passional considerations." Over the last twenty years, a number of philosophers have defended versions of virtue epistemology, approaches to the study of epistemic evaluation which are analogous to virtue theories in ethics (DePaul \& Zabzebski 2003; Hookway 2003). Such views have taken a number of different forms. Some involve recognizing that epistemic evaluation rests upon possession of capacities or skills which can be describes as "excellences." Others place emphasis upon the possession of favourable character traits, traits which enable us to form beliefs responsibly or to inquire well. Some virtue epistemologists argue that success in scientific investigations - or in other kinds of investigations - depends upon the possession of appropriate traits. For example, we must possess curiosity, openmindedness, and diligence in testing theories, and so on. One way in which our epistemic evaluations are manifested, according to this kind of view, is through affective or emotional responses. Real or "felt" doubt about our beliefs can take the form of a sort of epistemic anxiety or "fear." Someone who possesses the epistemic virtue will respond with doubt or anxiety about the belief in question. Just as fear alerts us to salient threats to our lives or activities, so doubt, epistemic anxiety, alerts us to salient problems, or salient weaknesses in our epistemic position. Epistemic virtues are varies, but we would expect that success in our reasoning and inquiry depends upon possessing traits such as curiosity, open-mindedness, and other traits. And if we take seriously James's first lecture on Pragmatism in 1906, we learn of the importance of temperament to our practices, recognizing that commitments to tough minded empiricism or to tender minded rationalism reflect different temperaments or character traits. When we are guided by these temperamental traits, we are guided by "passional considerations" and according to James, his kind of pragmatist has the ability to recognize the strengths and weaknesses of both sorts of temperamental trait. 


\section{Conclusion}

31 of virtue epistemology. All of these features contribute to his defence of the "will to believe" doctrine. Whether they are the whole of his argument may be less clear. But his insistence that, for example, belief in molecules is grounded in the prestige of those who tell us about them and van Fraassen's claim that the grounds on which we believe current fallible scientific results are similar to those employed in James's argument for the will to believe offers some support for the idea that James's reasons for believing in God draw on similar sorts of considerations.

\section{BIBLIOGRAPHY}

CLIFFORD W. K., (1879), “The Ethics of Belief,” in Lectures and Essays vol. 2, London, McMillan.

DEPAUL M. \& L. ZAGZEBSKI (eds.), (2003), Intellectual Virtue: Perspectives from Ethics and Epistemology, Oxford, Oxford University Press.

DEROSE K., (1992), “Contextualism and Knowledge Attributions," Philosophy and Phenomenological Research 52, 913-29.

VAN FRAASSEN B., (1984), "Belief and the Will," Journal of Philosophy, vol. 81, 235-56.

HоoKway Ch., (2000), Truth, Rationality, and Pragmatism, Oxford, Oxford University Press.

HоoкWAy Ch., (2003), “How to Be a Virtue Epistemologist,” in DePaul \& Zagzebski (eds.), 183-202.

HоoKway Ch., (2005), "Ramsey and Pragmatism: The Influence of Peirce,” in Maria Frapolli (ed.), The Philosophy of Ramsey, London, Rodopi, 182-93.

HоокWAy Ch., (2008), "Peirce and Skepticism," in J. Greco (ed.), The Oxford Handbook of Skepticism, New York, Oxford University Press, 310-29.

JAMES W., (1907) Pragmatism: A New Name For an Old Way of Thinking, Cambridge, Harvard University Press (1972).

JAMES W., (1897), The Will to Believe and Other Essays in Popular Philosophy, reprinted version, New York, Dover Publications.

LEVI I., (1998), "Pragmatism and Change of View," in C. J. Misak (ed.), Pragmatism. Canadian Journal of Philosophy, supplementary volume 24, 177-201.

PEIRCE C. S., (1982), Writings of Charles S. Peirce: A Chronological Edition, M. Fisch, E. Moore, C. Kloesel, N. Houser et al. (eds.), Bloomington, Indiana, Indiana University Press. (Refered to as W with volume number.)

PEIRCE C. S., (1931-60), Collected Papers of Charles Sanders Peirce, eight volumes, C. Hartshorne, P. Weiss \& A. Burks (eds.), Cambridge, Harvard University Press. (References take the form "CPn.m" giving volume and numbered section.) 
PEIRCE C. S., (1992), Reasoning and the Logic of Things, edited by Kenneth Laine Ketner, Cambridge, MA, Harvard University Press.

PEIRCE C. S., (1998), The Essential Peirce, two volumes, The Peirce Edition Project, Indianapolis, Indiana University Press. (References take the form "EPn:m" giving volume and page.)

\section{ABSTRACTS}

William James's paper "The Will to Believe" defends some distinctive and controversial views about the normative standards that should be adopted when we are reflecting upon what we should believe. He holds that, in certain special kinds of cases, it is rational to believe propositions even if we have little or no evidence to support our beliefs. And, in such cases, he holds that our beliefs can be determined by what he calls "passional considerations" which include "fear and hope, prejudice and passion, imitation and partisanship, the circumpressure of our caste and set" (1897: 9). On most occasions "we find ourselves believing, we hardly know how or why." When James allows passional considerations a major role in determining the rationality of belief and argues that it is rational to form beliefs in advance of the evidence, he can easily be understood as holding that belief can be responsible when it is not warranted by epistemological norms. Belief can be rational and responsible when the reasons which support it are entirely prudential or practical. The question I am concerned with here is: how far can James's argument in "The Will to Believe" be understood as an application of some views which are genuinely epistemological? One question we can ask about these views is: how far are they an application of a distinctively pragmatist approach to epistemological concerns about when belief is justified? One possibility is that James is making some original contributions to epistemology which may have echoes in contemporary epistemology. I shall argue that this interpretation of James's argument is more plausible than it at first appears.

\section{AUTHOR}

\section{CHRISTOPHER HOOKWAY}

The University of Sheffield

c.j.hookway[at]sheffield.ac.uk 